\title{
Sustainable Harvest of Mangaba (Hancornia speciosa) Fruits in Northern Minas Gerais, Brazil ${ }^{1}$
}

\author{
Isabela Lustz Portela Lima ${ }^{*, 2,3}$, Aldicir SCARiot ${ }^{3}$, AND \\ Aelton Biasi Giroldo ${ }^{2,3}$ \\ ${ }^{2}$ Departamento de Ecologia, Universidade de Brasília, Brasília, DF, Brazil \\ ${ }^{3}$ Embrapa Recursos Genéticos e Biotecnologia, Laboratório de Ecologia e Conservação, Parque Estação \\ Biológica, Brasília, DF, Brazil \\ *Corresponding author; e-mail: isabela_lustz@yahoo.com.br
}

\begin{abstract}
Sustainable Harvest of Mangaba (Hancornia speciosa) Fruits in Northern Minas Gerais, Brazil. The harvesting of non-timber forest products can contribute to conserving biodiversity and improving quality of life for rural communities. However, overexploitation can generate negative impacts on harvested populations, demanding the establishment of sustainable management practices. We estimated the maximum sustainable harvest of Hancornia speciosa Gomes (Apocynaceae) fruits in a savanna in northern Minas Gerais state, Brazil. The structure and population dynamics were analyzed in 70 permanent plots $(20 \times 50 \mathrm{~m})$ in the years $2008-$ 2011. A matrix population model based on life stages (seedlings, saplings, adults 1, adults 2) was used to calculate the population growth rate $(\lambda)$, the stable stage distribution and the elasticity, and to simulate the effects of different fruit harvesting levels. The population growth rate $(\lambda)$ value was $1.02\left(\mathrm{Cl}_{95 \%} 0.98\right.$ to 1.05$)$, the maximum sustainable fruit harvest rate was $87 \%$, and the elasticity analysis indicated that survival of the larger-size adults is the most important parameter to maintain the population. Apparently, the $H$. speciosa population is stable, which may indicate that the current harvesting level is not affecting population regeneration. However, other natural or anthropic disturbances, such as charcoal production and fire, can increase adult mortality, leading to population decline.
\end{abstract}

Extrativismo sustentável de frutos de mangaba (Hancornia speciosa) no norte de Minas Gerais, Brasil. O extrativismo de produtos florestais não madeireiros pode contribuir para conservar a biodiversidade e melhorar a qualidade de vida de comunidades rurais. Entretanto, a exploração excessiva pode impactar negativamente as populações exploradas, o que demanda o estabelecimento de práticas sustentáveis de manejo. Para estimar a taxa máxima de coleta sustentável dos frutos de Hancornia speciosa Gomes (Apocynaceae) realizamos um estudo em uma área de cerrado no norte do estado de Minas Gerais, Brasil. A estrutura e a dinâmica populacional foram analisadas em 70 parcelas permanentes $(20 \times 50 \mathrm{~m})$ nos anos $2008-2011$. Modelos de matriz populacional baseados em estágios de vida (plântulas, juvenis, adultos $1 \mathrm{e}$ adultos 2) foram utilizados para calcular a taxa de crescimento populacional $(\lambda)$, a distribuição estável de classes, a elasticidade e para simular os efeitos de diferentes níveis de coleta de frutos. A taxa de crescimento populacional $(\lambda)$ foi 1.02 (I $C_{95 \%} 0.98$ a 1.05), a taxa máxima de coleta sustentável é de $87 \%$ dos frutos e a análise de elasticidade mostrou que a sobrevivência dos adultos de maior tamanho é o parâmetro mais importante para a manutenção da população. Aparentemente a população de $H$. speciosa está estável, o que pode ser um indicativo de que o extrativismo praticado não está afetando a regeneração da população. Porém, outros distúrbios naturais ou antrópicos, como a produção de carvão e o fogo, podem aumentar a mortalidade de adultos levando a um declínio populacional.

Key Words: Non-timber forest products, matrix population model, sustainable management, savanna.

\footnotetext{
${ }^{1}$ Received 15 January 2013; accepted 13 August 2013; published online 17 September 2013.
} 


\section{Introduction}

The harvesting of non-timber forest products (NTFPs) has lower negative impacts on ecosystems than monoculture and livestock. This activity is potentially compatible with efforts to integrate biodiversity use and conservation (Shanley et al. 2002), despite possible ecological and livelihood risks associated with unplanned promotion of trade in NTFPs (Belcher and Schreckenberg 2007). NTFPs can contribute to improving income and supplying the needs of rural communities (Ticktin 2004; Pouliot 2012), the importance of these products being greater in the poorest communities (Godoy et al. 1995; Gunatilake et al. 1993; Ticktin 2004).

However, valorization and trade of NTFPs may lead to overharvesting, impacting vegetation at several levels, from individuals to ecosystems. The effects of harvesting are highly variable, depending on the plant part harvested, plant life history, environmental conditions, management, and the frequency and intensity of harvesting. The most direct ecological consequences are changes in survival rate, growth, and reproduction of the individuals harvested, modifying population structure and dynamics (Ticktin 2004). Plants' ability to compensate for losses resulting from harvesting depends on the resources available for their recovery (Gaoue and Ticktin 2007 and 2008), which may vary between sites. Generally, fruit harvesting does not affect the reproductive capacity of individuals, but can reduce population regeneration, which may affect its future persistence (Hall and Bawa 1993).

With more knowledge of population dynamics it is possible to use matrix population models to estimate the maximum sustainable harvest (e.g., Freckleton et al. 2003; Guimire et al. 2008; Ticktin and Nantel 2004; Zuidema and Boot 2002). These models are very useful, allowing harvesting impacts to be evaluated and optimal harvesting systems to be identified through growth rates, mortality, and recruitment of individuals over time (Caswell 2001).

For resources harvested, sustainable management practices that favor resource maintenance after extraction need to be developed (Guedje et al. 2007) so that the harvesting rates do not exceed the population's ability to replenish its individuals (Ticktin 2004). Knowing the ecology of the plant and assessing the quantitative impacts of harvesting are important for the development of management and conservation strategies of the exploited resource (Hall and Bawa 1993; Plowden 2004). This can be achieved by understanding the population dynamics and the quantitative analysis of the harvesting impact on natural populations (Guedje et al. 2007; Gunatilake et al. 1993; Hall and Bawa 1993).

To this end, we studied the dynamics of Hancornia speciosa Gomes (Apocynaceae), a common tree of the Brazilian savanna (known as Cerrado) and one of the most exploited species in northern Minas Gerais state, in southeastern Brazil. To estimate the impact of harvesting pressures and to contribute to sustainable harvesting and conservation of this species, we (1) evaluated whether or not the current fruit harvest level affects population growth rates and (2) estimated the maximum sustainable fruit harvest through matrix population models using information about fruit productivity, structure, and population dynamics. Results will help to define sustainable fruit harvesting levels and management practices to be implemented by the communities harvesting $H$. speciosa fruits.

\section{Materials and Methods}

\section{STUdy AREA}

The municipality of Rio Pardo de Minas (Figure 1), located $276 \mathrm{~km}$ from Montes Claros, in the northern region of Minas Gerais state,

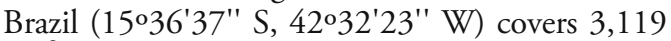
$\mathrm{km}^{2}$ and has 28,633 inhabitants, most of them in rural areas (IBGE 2008). The regional vegetation is a transition between Cerrado, the world's most endangered savanna, which sustains high levels of endemism (Myers et al. 2000), and the semiarid Caatinga. Most of the vegetation has been removed for charcoal production and the land is now mainly covered by commercial Eucalyptus plantations (Correia et al. 2010). The climate is semiarid and the average annual rainfall is 880 $\mathrm{mm}$; Aw climate predominates (Köppen classification), with rainy summers and dry winters (Nimer 1979). The study area, locally named Areião, covers 4,000 ha and is inhabited by Cerrado stricto sensu, a plant physiognomy dominated by small, gnarled trees with irregular and twisted branches (Ribeiro and Walter 1998). This area is well preserved, and despite having only rough access tracks, it represents an important source of NTFPs for local inhabitants and protects important headwaters. For these reasons, it is part of a larger area earmarked for the creation of the Sustainable Development Reserve Nascentes dos Gerais. 


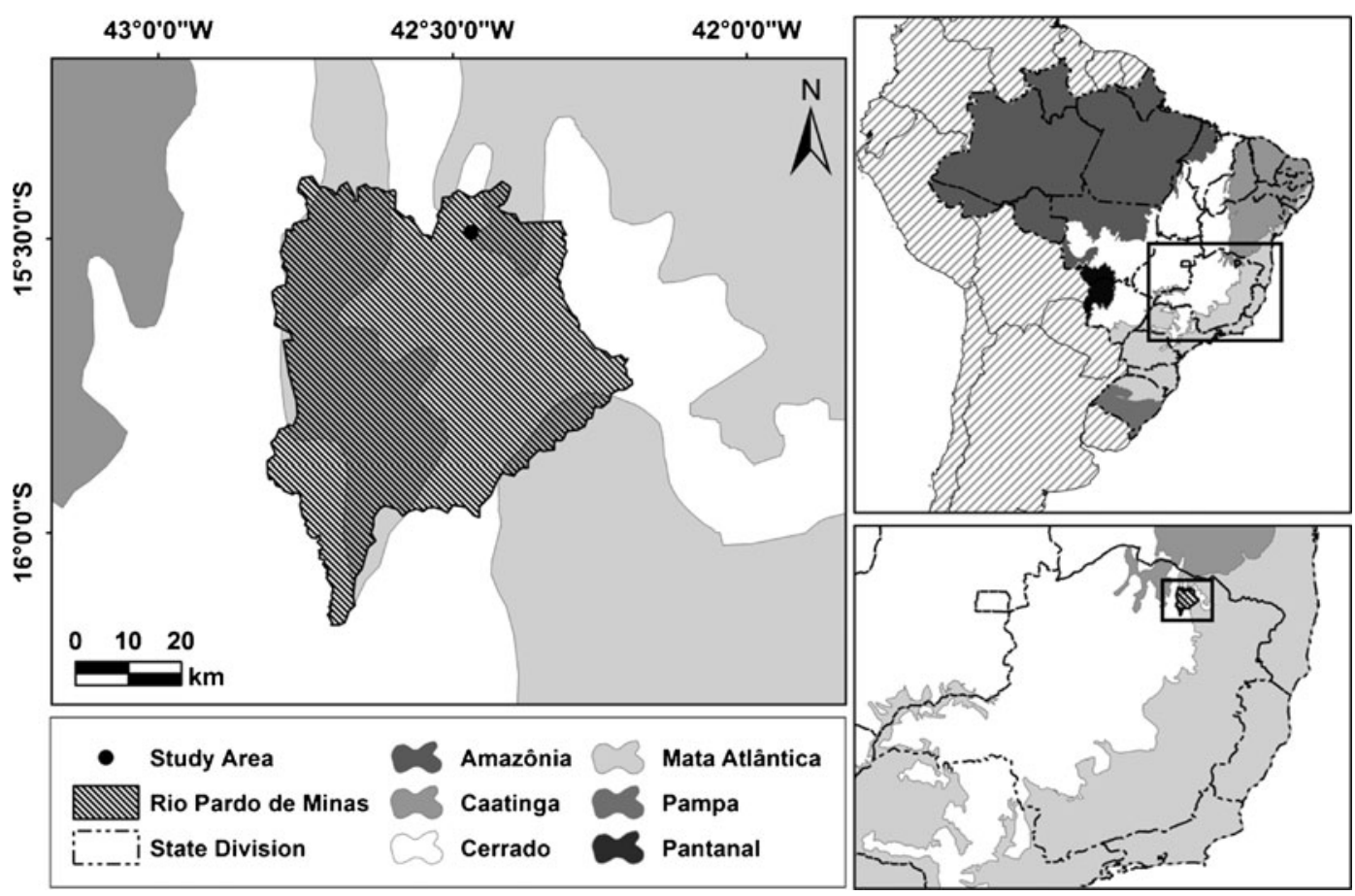

Fig. 1. Location of the study area, in the municipality of Rio Pardo de Minas, northern Minas Gerais state, Brazil.

The community Água Boa II, one of the 96 communities in the Rio Pardo de Minas municipality, comprises about 90 families of geraizeiros, rural people living in northern Minas Gerais state, with production systems heavily influenced by a close relationship with the environment (Nogueira 2009). In this community, the geraizeiros practice subsistence agriculture and obtain supplementary income from handicrafts made out of clay and licuri palm straw (Syagrus coronata [Mart.] Becc.). They also sell native fruits, mainly pequi (Caryocar brasiliense Cambess.) and mangaba (Hancornia speciosa Gomes), which are the most used and sought-after species in Areião (Lima et al. 2012). In this area, inhabitants also harvest medicinal plants and firewood, and raise cattle extensively. Harvested fruits are used for their own consumption and for sale at local and regional fairs and at a smallholders' cooperative, the Grande Sertäo (Gonçalves and Rosa 2005). The timber is used in buildings (such as houses), fences, corrals, and tools as well as for firewood in the production of artisanal pequi oil and clay utensils (Lima et al. 2012).

\section{Study Species}

Hancornia speciosa is a widely distributed tree in the Cerrado and Caatinga ecosystems (Almeida et al. 1998). It is drought-tolerant, grows well on oxisols and quartzipsamments, which are characterized by low organic matter, high acidity, and low nutrient availability (Ferreira and Marinho 2007). The plant is $2-15 \mathrm{~m}$ high, with an irregular crown, twisted branches, and a very rough trunk. The fruit is ellipsoid or round, measuring 2-6 cm, with 2-25 seeds, sweet and acidic pulp, and yellow skin and red spots. Flowering occurs from August to November, peaking in October, and fruiting takes place from July to October and January to April (Almeida et al. 1998). In northern Minas Gerais, however, fruits ripen from October to January, peaking in November (Lima and Scariot 2010).

H. speciosa is popularly named mangaba, meaning "something good to eat" in the TupiGuarani indigenous language (Silva Júnior 2005), a reference to its fruits, which have a high protein content and are aromatic, tasty, and nutritious (Parente et al. 1985). The fruits are widely accepted on the market, both fresh and processed (Almeida et al. 1998; Silva et al. 2001). In folk medicine, the bark is used against skin diseases and as a liver function stimulant (Almeida et al. 1998; Ferreira 1980), and the latex is used for tuberculosis and ulcer treatments (Ferreira 1973). This latex, known as mangaba milk, was widely 
used in the early twentieth century as a substitute for rubber (Hevea brasiliensis [Willd. ex A. Juss.] Müll. Arg.), despite its lower quality (Ferreira 1973).

Fruits are harvested from the natural population, with no planted areas known (Silva et al. 2006). Many smallholders boost their income with the harvest and sale of $H$. speciosa fruits, mainly in Sergipe, Bahia, and Minas Gerais states, the largest fruit producers (Soares et al. 2004). In Sergipe, mangaba plays an important role in the economy of more than 2,500 families, representing $60 \%$ of annual household income (Mota et al. 2007). In 2010, the federal government recognized the importance of this species for rural populations' income, and included it in the rural products minimum price policy, ensuring that production from rural communities fetches a minimum defined price.

Many $H$. speciosa populations have been destroyed, mostly in Northeastern Brazil (Pinheiro et al. 2001; Souza et al. 2005) and in the Cerrado, as a consequence of deforestation and land use changes. Currently, the trade volume of $H$. speciosa fruits does not meet market demand (Epstein 2004; Ferreira and Marinho 2007), indicating that harvesting is likely to continue to grow.

\section{Structure and Population Dynamics}

To analyze $H$. speciosa structure and population dynamics, we carried out a sampling in July 2008 in 70 randomly allocated permanent plots measuring $20 \mathrm{~m} \times 50 \mathrm{~m}$ (7.0 hectares) and a resampling in July 2011. We allocated plots in a 1,200hectare area in Areião, where fruit harvesting is most intense $\left(15^{\circ} 28^{\prime} 16^{\prime \prime} \mathrm{S}, 42^{\circ} 29^{\prime} 43^{\prime \prime} \mathrm{W}\right)$. In each plot, we recorded the diameter $30 \mathrm{~cm}$ above soil level $\left(\mathrm{DA}_{30}\right)$ of all $H$. speciosa individuals with $\mathrm{DA}_{30} \geq 5 \mathrm{~cm}$. In plants with $\mathrm{DA}_{30}<5 \mathrm{~cm}$ we measured the diameter at soil level (DSL) in $10 \mathrm{~m} \mathrm{x}$ $10 \mathrm{~m}$ subplots.

We assigned individuals into classes, based on trunk diameter, reproduction status, and mortality probability: seedlings $(<2 \mathrm{~cm}$ DAS, $90 \%$ of mortality probability, do not produce fruits); saplings (2 to $5 \mathrm{~cm}$ DAS, $50 \%$ of mortality probability, do not produce fruits), adults 1 (5 to $17 \mathrm{~cm} \mathrm{DA} \mathrm{DA}_{30}, 86.6 \%$ individuals produce on average $15.42 \pm 14.01$ fruits per plant) and adults 2 (17 to $40 \mathrm{~cm} \mathrm{DA}_{30}$, all individuals produce on average $72.06 \pm 47.13$ fruits per plant).

We tested the observed size class distribution fit to the reverse J-shaped curve with the negative exponential model $\left(y=a e^{-b x}\right)$ for the years 2008 and 2011. In this equation, $y$ represents the percentage of individuals in each class, $x$ is the size class midpoint, $a$ is the intercept, and $b$ is the curve slope (Hett and Loucks 1976). The $H$. speciosa population structure distributions in both years were compared by the KolmogorovSmirnov test.

We estimated the diameter increment, survival, and birth rate for each class for the three-year interval. To estimate diameter increment, we used the difference between plant diameters in 2008 and 2011. To estimate the birth rate we used the ratio between the number of seedlings and saplings absent in 2008 but present in 2011 and the total number of plants in 2008. We calculated survival for each class as the ratio between the number of individuals in class $i$ present in both years and the number of individuals in class $i$ present in 2008 .

\section{Sustainable Fruit Harvesting}

A life stage matrix population model of $H$. speciosa (Lefkovitch 1965) was constructed based on the fecundity of each class $(\mathrm{F})$, the probability of an individual surviving and moving on to the next class $(G)$, and the probability of an individual surviving and staying in the same class (R) (Caswell 2001).

To estimate individual fecundity, we calculated the ratio between numbers of seedlings present in 2011 and absent in 2008 and the total number of fruits produced in the population, and then multiplied this ratio by the number of fruits produced by that individual. Class fecundity was calculated by averaging individual fecundities. To estimate fruit productivity, we randomly sampled 30 adults in the harvesting area by removing and counting all fruits, including those found on the ground. The proportion of reproductive individuals in each class was estimated from a random sample of $60 \mathrm{H}$. speciosa individuals in the field. Fruit weight was estimated from eight batches of 50 fruits.

The matrix population model takes into account transition probabilities between classes for the 2008-2011 interval (Figure 2). The F, G, and $R$ values of each class were ordered in a transition matrix (A), where $a_{i j}$ represents the contribution of individuals in class $j$ to class $i$ over a three-year interval (Caswell 2001).

The population structure was represented by a vector $\left(\mathrm{N}_{0}\right)$, where each row corresponds to the 


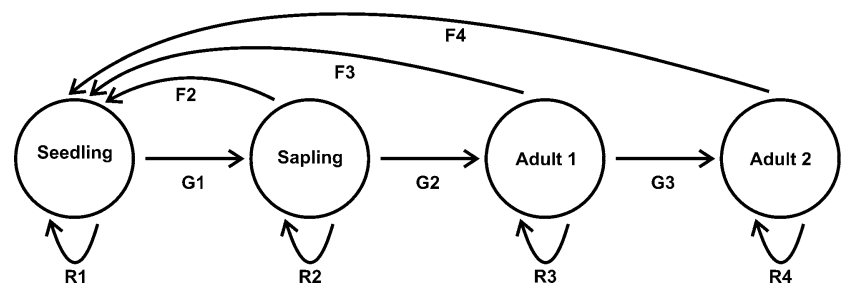

Fig. 2. Transition model between $H$. speciosa classes. $\mathrm{F}=$ fecundity, $\mathrm{G}=$ surviving and moving on to the next class; $\mathrm{R}=$ surviving and staying in the same class; $1=$ Seedlings; $2=$ Saplings; $3=$ Adults $1 ; 4=$ Adults 2 .

number of individuals in each class in 2008. We simulated changes in population structure over time by multiplying the transition matrix (A) by the vector $N_{0}$, so that $N_{t}=A^{t} \times N_{0}$, where $t=$ time periods. Increasing the $t$ value, the vector approaches a stable distribution, where the number of individuals in each class remains constant over time. From this stable distribution, we calculated the constant rate of population growth $(\lambda)$ by the ratio between $N_{t+1}$ and $N_{t} \cdot \lambda<$ 1 indicates population decline; $\lambda=1$ stability and $\lambda>1$ growth (Caswell 2001). We used the $\mathrm{G}$ test to compare the stable and the observed population structure distributions in both years.

The elasticity analysis was used to determine which matrix element contributes more to the value of $\lambda$, which indicates the most important element for population maintenance (Caswell 2001). We simulated the effect of different fruit harvesting levels ( $0 \%$ to $100 \%)$, through a reduction in seedling numbers, which indirectly represents a reduction in fecundity rates. The maximum sustainable fruit harvest indicates the percentage of fruits that could be harvested without significantly decreasing population growth $(\lambda \geq 1)$. We obtained the $\lambda$ significance with a $95 \%$ confidence interval, calculated by the bootstrap method, resampling the data 10,000 times (Caswell 2001). All analyses were conducted in the R Program (R Development Core Team 2012) using the Popbio (Stubben and Milligan 2007) and Deducer (Fellows 2012) packages.

\section{ETHNOBOTANICAL SURVEY}

Before starting to collect ethnobotanical data, meetings were held with the community to present the research objectives and to request prior informed consent, which was then approved (process 02000.001131/2008-03) by the Board of Genetic Heritage Management (CGEN). This federal institution is in charge of issuing permits to carry out research with traditional knowledge associated with genetic resources, and at the end of the study it also approved the final report.

Semi-structured interviews were conducted with seven of the eight members of the Harvesters Group, an organized group that collects native fruits to sell to the Grande Sertáo Cooperative. Using the "snowball" sampling method (Martin 1995), the six most experienced harvesters were selected from among the 30 harvesters who individually collect fruits, totaling 13 interviews. In the interviews, harvesters characterized the level of fruit harvesting, local management practices, and the plant's ecological characteristics.

\section{Results and Discussion}

In total, $436 \mathrm{H}$. speciosa individuals (106.5 plants.ha ${ }^{-1}$ ) were sampled in 2008-205 seedlings $\left(61.4 \mathrm{ha}^{-1}\right), 65$ saplings $\left(21.5 \mathrm{ha}^{-1}\right), 95$ adults $1(13.5$ $\left.\mathrm{ha}^{-1}\right)$, and 71 adults $2\left(10.1 \mathrm{ha}^{-1}\right)$. In 2011, 332 individuals (76.0 plants.ha ${ }^{-1}$ ) were sampled-76 seedlings $\left(22.8 \mathrm{ha}^{-1}\right), 77$ saplings $\left(23.1 \mathrm{ha}^{-1}\right), 107$ adults $1\left(15.3 \mathrm{ha}^{-1}\right)$, and 72 adults $2\left(10.2 \mathrm{ha}^{-1}\right)$. The stable distribution projected by the matrix population model $(37.1 \%$ of seedlings, $12.3 \%$ of saplings, $29.4 \%$ of adults 1 , and $21.1 \%$ of adults 2 ) is different from the distribution observed in 2008 $(\mathrm{G}=18.90, \mathrm{df}=3, \mathrm{p}=0.0002)$ and in $2011(\mathrm{G}=$ $8.74, \mathrm{df}=3, \mathrm{p}=0.0329$ ).

Diameter class distribution in both years was similar to a reverse J-shaped curve $\left(\mathrm{R}^{2}>0.7, \mathrm{p}<\right.$ 0.0001 ), with lower fitting in 2011 than in 2008 (Figure 3 ). The population structure was significantly different between these years $(\mathrm{D}=0.25$, $\mathrm{p}<0.0001)$. This pattern, with many individuals in the first class size and a reduced number of individuals in subsequent classes, is typical of stable or growing populations (Condit et al. 1998; Peters 1994), despite the fact that several authors have found it in declining populations (Condit et al. 1998; Virillo et al. 2011; Wright et al. 2003). The reduction of $63 \%$ in the number of seedlings from 2008 to 2011 may have been 


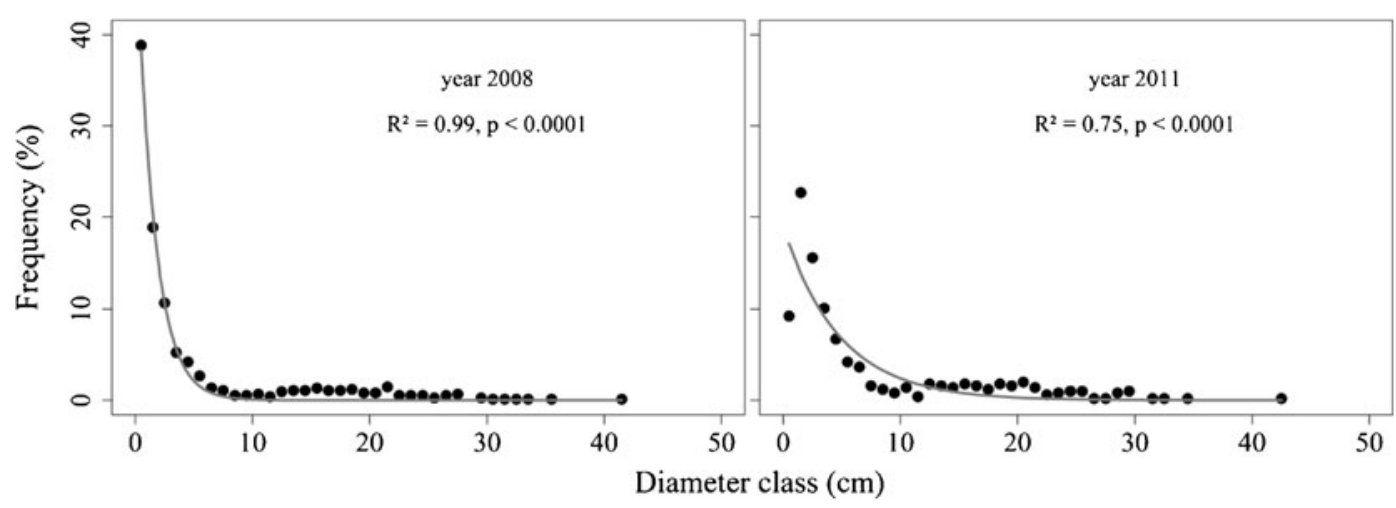

Fig. 3. Class size distribution of H. speciosa population in 2008 and 2011 . The p value shows the significance of the fit to reverse J-shaped curve, whereas $\mathrm{R}^{2}$ indicates the percentage of the dependent variable explained by the theoretical model.

caused by the 2010 fire incident in part of the population. According to Medeiros and Miranda (2005), this type of fire in the Cerrado mainly causes the mortality of plants below $50 \mathrm{~mm}$ in diameter.

All adults 2 and $86.6 \%$ of adults 1 set fruits, with wide variation between plants (1 to 829 fruits per plant), and an average $15.4 \pm 14.0$ fruits per adult 1 and $72.1 \pm 47.1$ fruits per adult 2 . On average a fruit weighs $20.4 \pm 1.0 \mathrm{~g}$. Considering that in one hectare, 15.3 adults 1 and 10.2 adults occur, this area can produce $939.5 \pm 665.9$ fruits, which represents $19.2 \pm 14.5 \mathrm{~kg}$. In the $1,200-$ hectare area, potential production is $23,040 \pm$ $17,400 \mathrm{~kg}$ of fruits annually.

In 2002 , the community harvested $1,340 \mathrm{~kg}$ of H. speciosa fruits (Carvalho 2007), and in 2006 only $873 \mathrm{~kg}$ (Sano et al. 2007), 6\% and 4\% of the potential production, respectively. Usually harvesters collect fruits in the areas closest to their residences, for only two days, with a harvester collecting on average $25 \mathrm{~kg}$ per day. Harvesters do not manage plants or the population to either increase production or facilitate harvesting. Most fruits fail to be harvested either because they are still immature or because they are on the higher branches, where they cannot be reached. Only fruits that are not fully ripe (named de vez by harvesters) are harvested, because fully ripe fruits are easily squashed during transport and cleaning. Harvested fruits are placed in boxes or plastic bags and transported to harvesters' residences to be washed and sold at farmers' fairs or delivered to the cooperative processing plant. The demand for fruit from regional cooperatives is high, but harvesters face difficulties with the overgrown tracks that access the area, incurring costs with fruit transportation to cooperatives, as well as the disadvantages of highly perishable fruit and lack of local infrastructure to process them. Solving some of these bottlenecks may foster harvesting.

Fecundity (F), surviving and staying in the same class (R), and surviving and moving on to the next class $(G)$ were determined from a transition matrix (A) for the H. speciosa population (Table 1). The mortality rate was higher in seedlings $(51.2 \%)$ than in saplings $(12.3 \%)$, adults $1(6.3 \%)$, and adults $2(1.5 \%)$. The birth rate was $3.0 \%$. The diameter increment in the three-year period was higher in saplings $(0.94 \pm$ $0.84 \mathrm{~cm})$ than in seedlings $(0.68 \pm 0.67 \mathrm{~cm})$, adults $1(0.64 \pm 1.59 \mathrm{~cm})$, and adults $2(0.03 \pm$ $2.11 \mathrm{~cm})$. The estimated population growth rate

Table 1. H. SPECIOSA POPULATION TRANSITION MATRIX (A) IN THE AREIÄO AREA, NORTHERN MINAS GERAIS STATE, BRAZIL.

\begin{tabular}{lllll}
\hline \hline & Seedling & Sapling & Adult 1 & Adult 2 \\
\hline Seedling & 0.32158 & 0 & 0.20000 & 1.08000 \\
Sapling & 0.16621 & 0.59943 & 0 & 0 \\
Adult 1 & 0 & 0.27748 & 0.88666 & 0 \\
Adult 2 & 0 & 0 & 0.05017 & 0.98467 \\
\hline
\end{tabular}




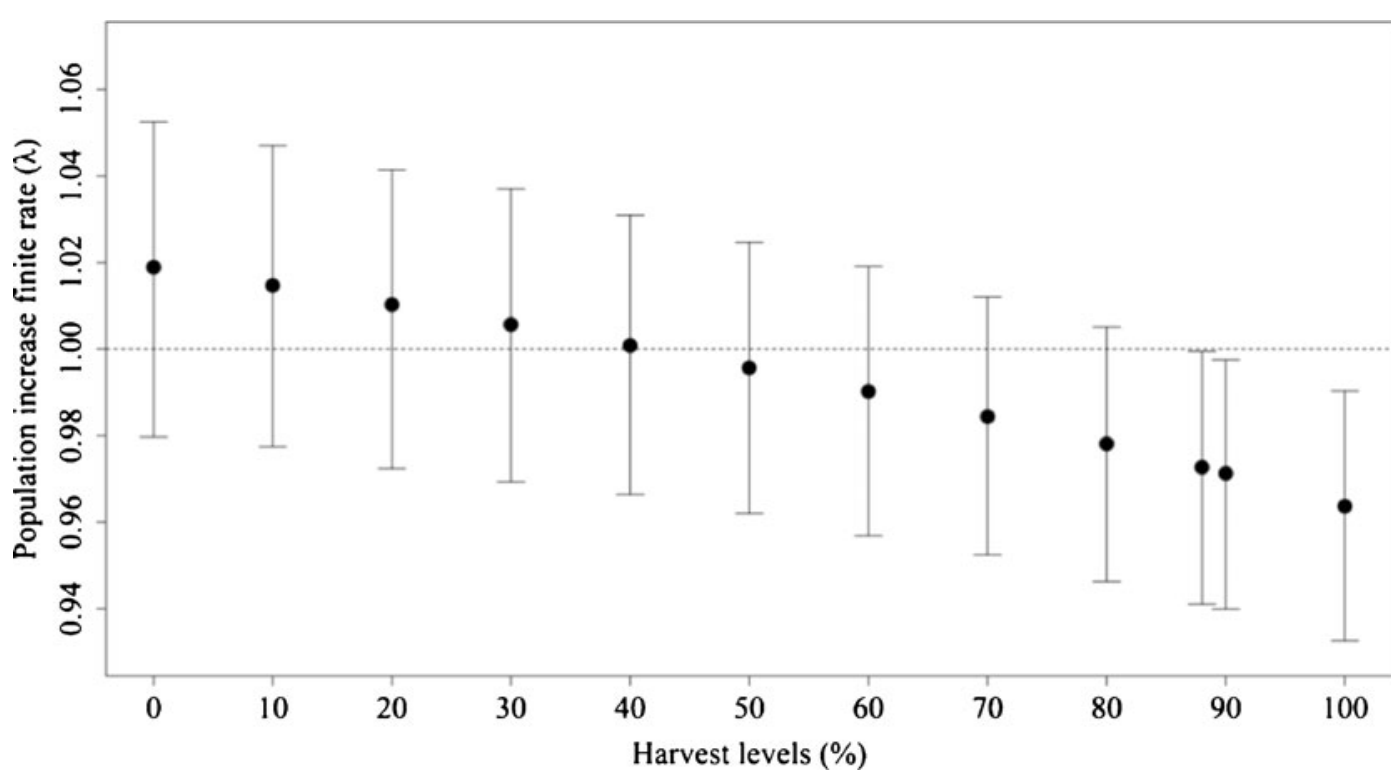

Figure 4. Simulation of different harvesting levels through seedling reduction and their population growth rates $(\lambda)$ with confidence interval $\left(\mathrm{IC}_{95 \%}\right)$. Harvesting over $87 \%$ of the fruits will reduce $H$. speciosa population growth $(\lambda<1)$.

$\left(\lambda=1.02, \mathrm{CI}_{95 \%}=0.98\right.$ to 1.05$)$ indicates that the population is stable, contrary to the perception of $46.2 \%$ of the harvesters who believed that $H$. speciosa density has decreased because many have died or have been cut down for charcoal.

The maximum sustainable fruit harvest is $87 \%$ $(\lambda=1.0 ; 95 \%$ confidence interval), and harvesting above this level may cause a fall in population growth $(\lambda<1)$ (Figure 4). Generally, high levels of fruit harvest allow the population to persist over time if the harvesting activity does not damage other parts of the tree (Emanuel et al. 2005; Ticktin 2004). The harvesters reported that breaking or removing branches during fruit harvesting is a common practice in the area, which damages plants and removes flowers. To avoid this kind of tree damage, harvesters should use a pole with a hook for fruit harvesting, which eliminates the need for tree climbing (Lima and Scariot 2010).
Elasticity analysis identifies $\lambda$ sensitivity to changes in demographic parameters, indicating priority actions for species conservation (Caswell 2001; Zuidema et al. 2007). For H. speciosa, the most important parameter to maintain the population is the survival of adults 2 , contributing to $41 \%$ of $\lambda$ value (Table 2). Population growth is very sensitive to adult mortality and cutting down these individuals for charcoal production, a common practice in the region, harms the long-term persistence of the population.

Population decline could also be attributed to other biotic and abiotic factors (Hall and Bawa 1993), such as fire (Sinha and Brauldt 2005), a common disturbance in the Cerrado (Miranda et al. 2002), which kills seedlings of many species (Hoffmann 1998). According to the harvesters, fire kills $H$. speciosa adults 2 and seedlings, and only adults 1 survive to regrow later, taking up to

Table 2. ELASTICITY ANALYSIS FOR THE POPULATION OF H. SPECIOSA IN THE AREIÃO AREA, NORTHERN MINAS GERAIS STATE, BRAZIL. EACH MATRIX VALUE INDICATES THE CONTRIBUTION TO THE $\lambda$ VALUE.

\begin{tabular}{lllll}
\hline \hline & Seedling & Sapling & Adult 1 & Adult 2 \\
\hline Seedling & 0.020963 & 0.000942 & 0.009533 & 0.031114 \\
Sapling & 0.041590 & 0.052351 & 0.002370 & 0 \\
Adult 1 & 0 & 0.043017 & 0.311608 & 0.022409 \\
Adult 2 & 0 & 0 & 0.053523 & 0.410574 \\
\hline
\end{tabular}


two years for the plant to set fruits again. The matrix model simulations indicated that an increase of $20 \%$ in the mortality of adults 2 leads to population decline $(\lambda<1)$.

\section{Conclusions and Management Implications}

The area studied has a great and underexploited potential for $H$. speciosa fruit harvesting. Fruit perishability and the poor quality of access roads hinder an increase in fruit volume harvested. Apparently, the population of $H$. speciosa in Areião is stable $\left(\lambda=1.02, \mathrm{CI}_{95 \%} 0.98\right.$ to 1.05$)$ and fruit harvesting at the current level is not affecting population recruitment. Current harvesting levels (4\% to $6 \%)$ are well below the maximum sustainable harvest rate, and harvesting can be substantially increased if some management practices are adopted: (a) fruit harvest should not exceed $87 \%$ of the available fruits, otherwise it could compromise population regeneration; (b) fruits should be removed with a pole with a hook, reducing tree damage like broken branches and dropped flowers.

The harvesting intensity can increase, reaching $87 \%$ of the fruit without hindering population persistence, but the most important parameter to maintain the population over time is the survival of adults 2 rather than fecundity rates. Therefore, priority actions for $H$. speciosa population conservation are: (a) protection of populations from fire because this kills adults 2 and reduces adults 1 productivity, and (b) eliminating the cutting of adult plants because population growth is very sensitive to adult mortality.

\section{Acknowledgements}

Our work was supported by Embrapa Genetic Resources and Biotechnology (Cenargen), Biodiversity Program Brazil-Italy, PPP-Ecos Program (ISPN/UNDP), PESCO Program (IEB/ISPN/ PNUD), and CAPES. We thank Marcelo B. Medeiros, Anderson C. Sevilha, João R. Correia, Nilton F. Barbosa, Juarez P. Amaral, Washington L. Oliveira, Daniel R. Oliveira, and Victor F. Lima for logistic and technical support. All harvesters in the community, especially Mrs. Maria Lúcia de O. Agostinho and Mr. Antônio José Agostinho, contributed significantly during the fieldwork. Isabel B. Schmidt helped with the matrix analysis. Two anonymous reviewers provided valuable comments.

\section{Literature Cited}

Almeida, S. P., C. E. Proença, S. M. Sano, and J. F. Ribeiro. 1998. Cerrado: espécies vegetais úteis. Planaltina, Brazil: Embrapa CPAC.

Belcher, B. and K. Schreckenberg. 2007. Commercialisation of non-timber forest products: A reality check. Development Policy Review 25(3):355-377.

Carvalho, I. S. H. 2007. Potenciais e limitaçôes do uso sustentável da biodiversidade do Cerrado: um estudo de caso da Cooperativa Grande Sertão no Norte de Minas Gerais. Dissertação de Mestrado em Desenvolvimento Sustentável. Universidade de Brasília. Brasília, DF.

Caswell, H. 2001. Matrix population models: Construction, analysis and interpretation. Sunderland, Massachusetts: Sinauer Associates, Inc.

Condit, R., R. Sukumar, S. P. Hubbell, and R. B. Foster. 1998. Predicting population trends from size distributions: A direct test in a tropical tree community. The American Naturalist 152(4):495-509.

Correia, J. R., P. G. Bustamante, I. L. P. Lima, W. L. Oliveira, L. A. Cavechia, S. M. Sano, and A. O. Scariot. 2010. Construção do conhecimento sobre uso e conservação da biodiversidade em áreas de Geraizeiros no Norte de Minas Gerais. In: Etnoecologia em Perspectiva: natureza, cultura e conservação, eds., A. G. C. Alves, F. J. B., Souto, and N. P. Peroni, 229-247. Recife, Brazil: NUPEEA.

Emanuel, P. L., C. M. Shackleton, and J. S. Baxter. 2005. Modelling the sustainable harvest of Sclerocaryabirrea subsp. caffra fruits in the South African lowveld. Forest Ecology and Management 214:91-103.

Epstein, L. 2004. Mangaba: "coisa boa de comer". Bahia Agrícola 6(2):19-22.

Fellows, I. 2012. Deducer: A data analysis GUI for R. Journal of Statistical Software 49(8): 1-15.

Ferreira, E. G. and S. J. O. Marinho. 2007. Produção de frutos de mangabeira para consumo in natura e industrialização. Tecnologia \& Ciência Agropecuária 1:9-14.

Ferreira, M. B. 1973. Frutos comestíveis do Distrito Federal - III: piqui, mangaba, marolo e mamaozinho. Cerrado 20:22-25.

. 1980. Plantas portadoras de substâncias medicamentosas de uso popular, nos cerrados de Minas Gerais. Informe Agropecuário 6(61):19-23. 
Freckleton, R. P., D. M. Silva Matos, M. L. A. Bovi, and A. R. Watkinson. 2003. Predicting the impacts of harvesting using structured population models: The importance of density-dependence and timing of harvest for a tropical palm tree. Journal of Applied Ecology 40(5):846-858.

Gaoue, O. G. and T. Ticktin. 2007. Patterns of harvesting foliage and bark from the multipurpose tree Khaya senegalensis in Benin: Variation across ecological regions and its impacts on population structure. Biological Conservation 137(3):424-436.

- and T. Ticktin. 2008. Impacts of bark and foliage harvest on Khaya senegalensis (Meliaceae) reproductive performance in Benin. Journal of Applied Ecology 45:34-40.

Godoy, R., N. Brokaw, and D. Wilkie. 1995. The effect of income on the extraction of non-timber tropical forest products: Model, hypotheses, and preliminary findings from the Sumu Indians of Nicaragua. Human Ecology 23:29-52.

Gonçalves, B. and H. S. Rosa. 2005. Cooperativa Grande Sertão: articulando populaçóes e diversidades do Norte de Minas Gerais. Agriculturas 2:17-21.

Guedje, N. M., P. A. Zuidema, H. During, B. Foahrom, and J. Lejoly. 2007. Tree bark as a non-timber forest product: The effect of bark collection on population structure and dynamics of Garcinia lucida Vesque. Forest Ecology and Management 240:1-12.

Guimire, S. K., O. Gimenez, R. Pradel, D. McKey, and Y. Aumeeruddy-Thomas. 2008. Demographic variation and population viability in a threatened Himalayan medicinal and aromatic herb Nardostachys grandiflora: Matrix modeling of harvesting effects in two contrasting habitats. Journal of Applied Ecology 45:41-51.

Gunatilake, H. M., D. M. A. H. Senaratne, and P. Abeygunawardena. 1993. Role of nontimber forest products in the peripheral communities of knuckles national wilderness area of Sri Lanka: A farming systems approach. Economic Botany 47(3):275-281.

Hall, P. and K. Bawa. 1993. Methods to assess the impact of extraction of non-timber tropical forest products on plant populations. Economic Botany 47(3):234-247.

Hett, J. M. and O. L. Loucks. 1976. Age structure models of Balsam Fir and Eastern
Hemlock. Journal of Ecology 64(3):10291044.

Hoffmann, W. A. 1998. Post-burn reproduction of woody plants in a neotropical savanna: The relative importance of sexual and vegetative reproduction. Journal of Applied Ecology 35(3):422-433.

IBGE (Instituto Brasileiro de Geografia e Estatística). http://www.ibge.gov.br/cidadesat/ default.php (19 August 2008).

Lefkovitch, L. P. 1965. The study of population growth in organisms grouped by stages. Biometrics 21:1-18.

Lima, I. L. P. and A. Scariot. 2010. Boas Práticas de Manejo para o Extrativismo Sustentável da Mangaba. Brasília, Brazil: Embrapa Recursos Genéticos e Biotecnologia.

- A. Scariot, M. B. Medeiros, and A. C. Sevilha. 2012. Diversidade e uso de plantas do Cerrado em comunidade de Geraizeiros no norte do Estado de Minas Gerais, Brasil. Acta Botanica Brasilica 26:675-684.

Martin, G. J. 1995. Ethnobotany: A methods manual. London: Chapman \& Hall.

Medeiros, M. B. and H. S. Miranda. 2005. Mortalidade pós-fogo em espécies lenhosas de campo sujo submetido a três queimadas prescritas anuais. Acta Botanica Brasilica 19:493-500.

Miranda, H. S., M. M. C. Bustamante, and A. C. Miranda. 2002. The fire factor. In: The Cerrados of Brazil: Ecology and natural history of a neotropical savanna, eds., P. S. Oliveira and R. J. Marquis, 51-68. New York: Columbia University Press.

Mota, D. M., H. Schmitz, J. F. S. Júnior, N. B. Jesus, E. O. Pereira, R. F. A. Rodrigues, J. V. Santos, and F. F. Curado. 2007. As Catadoras de Mangaba: problemas e reivindicaçóes. Belém, Brazil: Embrapa Amazônia Oriental.

Myers, N., R. A. Mittermeier, C. G. Mittermeier, G. A. B. Fonseca, and J. Kent. 2000. Biodiversity hotspots for conservation priorities. Nature 403: 853-858.

Nimer, E. 1979. Climatologia do Brasil, vol. 4. SUPREN/IBGE.

Nogueira, M. C. R. 2009. Gerais a dentro e a fora: Identidade e territorialidade entre Geraizeiros do Norte de Minas Gerais. Tese de doutorado, Departamento de Antropologia, Universidade de Brasília. Brasília, DF.

Parente, T. V., A. L. Borgo, and J. W. B. Machado. 1985. Características físico-químicas de frutos 
de mangaba (Hancornia speciosa Gom.) do Cerrado da região geoeconômica do Distrito Federal. Ciência e Cultura 37:95-98.

Peters, C. M. 1994. Sustainable harvest of nontimber plant resources in tropical moist forest: An ecological primer. Washington, D.C.: Biodiversity Support Program.

Pinheiro, C. S. R., D. N. Medeiros, C. E. C. Macedo, and M. A. I. Alloufa. 2001. Germinação in vitro de mangabeira (Hancornia speciosa Gomez) em diferentes meios de cultura. Revista Brasileira de Fruticultura 23(2):413-416.

Plowden, C. 2004. The ecology and harvest of andiroba seeds for oil production in the Brazilian Amazon. Conservation \& Society 2(2):251-272.

Pouliot, M. 2012. Contribution of "Women's Gold" to West African livelihoods: The case of shea (Vitellaria paradoxa) in Burkina Faso. Economic Botany 66(3):237-248.

R Development Core Team, 2012. R: A language and environment for statistical computing. Vienna: R Foundation for Statistical Computing.

Ribeiro, J. F. and B. M. T. Walter. 1998. Fitofisionomias do Bioma Cerrado. In: Cerrado: ambiente e flora, eds., S. Sano and S. Almeida, 89-166. Brasília, Brazil: Embrapa-CPAC.

Sano, S. M., I. L. P. Lima, and J. R. Correia. 2007. Avaliação participativa do extrativismo de mangaba (Hancornia speciosa Gomes) em Rio Pardo de Minas, MG. In: Agricultura familiar, políticas públicas e inclusão social: anais do 70 Congresso Brasileiro de Sistemas de Produção, orgs., H. E. M. Vasconcelos, V. H. Oliveira, and A. H. Oster, 1-7. Fortaleza, Brazil: Embrapa Agroindústria Tropical.

Shanley P., A. R. Pierce, S. A. Laird, and A. Guillen. 2002. Tapping the green market: Certification and management of non-timber forest products. London: Earthscan Publications.

Silva, D. B., J. A. Silva, N. T. V. Junqueira, and L. R. M. Andrade. 2001. Frutas do Cerrado. Brasília, Brazil: Embrapa Informação Tecnológica.

Silva, S. M. C., J. L. Nascimento, and R. V. Naves. 2006. Produção de mangabeira (Hancornia speciosa Gomes) irrigada e adubada nas condiçôes do Estado do Goiás. Bioscience Journal 22(2):43-51.
Silva Júnior, M. C. 2005. 100 árvores do cerrado: Guia de campo. Brasília, Brazil: Rede de Sementes do Cerrado.

Sinha, A. and S. Brauldt. 2005. Assessing sustainability of non-timber forest product extractions: How fire affects sustainability. Biodiversity and Conservation 14:3537-3563.

Soares, F. P., R. Paiva, R. C. Nogueira, L. M. Oliveira, D. R. G. Silva, and P. D. O. Paiva. 2004. Cultura da mangabeira (Hancornia speciosa Gomes). Boletim Agropecuário 67:1-12.

Souza, C. S., S. A. Silva, M. A. P. C. Costa, A. C. V. L. Dantas, A. A. Fonseca, C. A. L. C. Costa, W. A. B. Almeida, and C. P. Peixoto. 2005. Mangaba: perspectivas e potencialidades. Bahia Agrícola 7:29-31.

Stubben, C. J. and B. G. Milligan, B.G. 2007. Estimating and analyzing demographic models using the popbio Package in R. Journal of Statistical Software 22:11.

Ticktin, T. 2004. The ecological implications of harvesting non-timber forest products. Journal of Applied Ecology 41:11-21.

_ and P. Nantel. 2004. Dynamics of harvested populations of the tropical understory herb Aechmea magdalenae in old-growth versus secondary forests. Biological Conservation 120(4):461-470.

Virillo, C. B., F. R. Martins, J. Y. Tamashiro, and F. A. M. dos Santos. 2011. Is size structure a good measure of future trends of plant populations? An empirical approach using five woody species from the Cerrado (Brazilian savanna). Acta Botanica Brasilica 25:593-600.

Wright, S. J., H. C. Muller-Landau, R. Condit, and S. P. Hubbell. 2003. Gapdependent recruitment, realized vital rates, and size distributions of tropical trees. Ecology 84(12):3174-3185.

Zuidema, P. A. and R. G. A. Boot. 2002. Demography of the Brazil nut tree (Bertholletia excelsa) in the Bolivian Amazon: Impact of seed extraction on recruitment and population dynamics. Journal of Tropical Ecology 18:1-31.

$\longrightarrow$, H. Kroon, and J. A. Werger. 2007.Testing sustainability by prospective and retrospective demographic analyses: Evaluation for palm leaf harvest. Ecological Applications 17:118-128. 